showed a significant increase in VEGF level $(343.35(190.62 ; 561.28) \mathrm{pg} / \mathrm{ml})$ in the group of high positive ACCP $(>60 \mathrm{U} / \mathrm{ml})$ compared with the group of low positive ACCP $(\leq 60 \mathrm{U} / \mathrm{ml})$ - $470.23(324.3,676.85) \mathrm{pg} / \mathrm{ml}(\mathrm{p}=0,005)$. Using ANOVA variance analysis, it was found that the level of anti-CCP in the blood of studied RA patients influences the VEGF level in blood ( $K W=7,88 ; p=0,005)$ Conclusions: In patients with RA duration $<2$ years VEGF levels in the blood was $30 \%$ higher than in patients with a prolonged course of RA. Concentration of VEGF in the blood increased 2-fold with a high degree of RA activity. Levels of VEGF in the blood were 1.5 times higher in the patients with anti-CCP levels $>60$ $\mathrm{U} / \mathrm{ml}$ compared to low positive anti-CCP patients. The high level of VEGF may be a marker of severe clinical course of RA, the high rate of disease progression and the development of early joint destruction

Disclosure of Interest: None declared

DOI: 10.1136/annrheumdis-2017-eular.2373

\section{AB0197 SUBCLINICAL INTERSTICIAL LUNG DISEASE IN EARLY RHEUMATOID ARTHRITIS}

C. Fernández-Díaz ${ }^{1}$, M. Calderón-Goerckel ${ }^{1}$, J. Martin-Varillas ${ }^{1}$,

B. Atienza-Mateo ${ }^{1}$, A. Corrales-Martinez ${ }^{1}$, V. Portilla-Gonzalez ${ }^{1}$, V. Calvo-Rio ${ }^{1}$ J. Rueda-Gotor ${ }^{1}$, N. Palmou-Fontana ${ }^{1}$, M. Agudo-Bilbao ${ }^{1}$, N. Vegas-revenga ${ }^{1}$, L. Domingues-Casas ${ }^{1}$, J. Cifrian-Martinez ${ }^{2}$, M.A. Gonzalez-Gay ${ }^{1}$, R. Blanco ${ }^{1}$.

${ }^{1}$ Rheumatology, Hospital Universitario Marques de Valdecilla, IDIVAL;

2 Pneumology, Hospital Universitario Marques de Valdecilla., Santander, Spain

Background: Interstitial lung disease (ILD) is a severe extra-articular complication of Rheumatoid Arthritis (RA). The decrease in DLCO diffusion is the most sensitive value for the detection of ILD, DLCO is also a prognostic factor.

Objectives: To study the prevalence of subclinical lung involvement in early RA.

Methods: Cross-sectional study of lung involvement in early RA. The following criteria were used: A) RA according to the EULAR-2010 criteria. B) Early RA if evolution from the onset of symptoms to the diagnosis of RA was less than one year. C) Lung affectation if DLCO diffusion was lower than $80 \%$. In each patient we evaluate: a) presence of dyspnea according to MMRC (Modified British Medical Research Council) scale; B) Respiratory function tests (FVC, FEV1, FEV1/FVC; C) DLCO; classifying the degree in: i) normal $>80 \%$ (mild decrease $80-60 \%$ ); ii) Moderate decrease $(60-40 \%)$ and iii) Severe reduction $(<40 \%)$; D) Chest $x$-ray: assessed by radiologist. E) Joint activity of RA (DAS28), F) CRP and ESR. G) RF, CCPA, H) Presence of atheroma plaque on carotid ultrasound. Quantitative variables were expressed as mean $\pm S D$ or median [IQR] and were compared with the Student t or Mann Whitney U test, respectively. Dichotomous variables were expressed as percentages and compared using the chi-square test. Statistical analysis was performed with the SPSS 15.0 program.

Results: 20 patients ( 15 women/5 men) with early RA were studied; mean age of $54.1 \pm 13.4$ years. Some patients were using disease-modifying antirheumatic drugs (DMARDs) prior to performing respiratory function tests (PFR): methotrexate (7) 3 of them with less than 14 days of treatment, hydroxychloroquine (4), sulfasalazine (1). The table shows the main characteristics of patients according to pressence of lung disease. We observed a decrease in DLCO in 15/20 patients $(75 \%)$ who were mild $(\mathrm{DLCO}<80 \%)$ in $4(27 \%)$; Moderate (DLCO $<60 \%)$ in 9 $(60 \%)$ and severe (DLCO $<40 \%)$ in $2(13 \%)$. Chest $x$-ray showed these alterations in 3 patients: signs of air trapping, laminar atelectasis and scarring tracts. There were no alterations in FVC in any patient.

Table 1

\begin{tabular}{lccc}
\hline & $\begin{array}{c}\text { With lung involvement } \\
(\mathrm{n}=15)\end{array}$ & $\begin{array}{c}\text { Without lung involvement } \\
(\mathrm{n}=5)\end{array}$ & $\mathrm{P}$ \\
\hline Age. mean & $56.3 \pm 13.11$ & $55.6 \pm 15.69$ & 0.55 \\
Sex (W/M) & $13 / 2$ & $3 / 2$ & 0.03 \\
Smokers or ex smokers, $\mathrm{n}(\%)$ & $10(66.7)$ & $1(20)$ & 0.06 \\
CCP Antibody, positive $\mathrm{n}(\%)$ & $8(53.3)$ & $2(40)$ & 0.60 \\
Titer, median [IQR] & $430.5[165.8-1874.2]$ & $47[35-59]$ & 0.23 \\
RF Positive, $\mathrm{n}(\%)$ & $8(53.3)$ & $2(66)$ & 0.6 \\
RF titer. median [IQR] & $213[67.5-334.75]$ & $135[74-196]$ & 0.6 \\
ESR mean/ CRP mean & $32.1 \pm 21.4 / 4.7 \pm 7.8$ & $24.6 \pm 21.8 / 0.80 \pm 0.83$ & $0.84 / 0.21$ \\
DAS28, mean & $5.04 \pm 1.03$ & $4.48 \pm 0.85$ & 0.49 \\
Bone erosions $\mathrm{X}$ ray, $\mathrm{n}(\%)$ & $1(6.7)$ & $1(20)$ & 0.60 \\
Carotid plaque, $\mathrm{n}(\%)$ & $8(53.3)$ & $2(40)$ & 0.60 \\
Extra articular manifestation, $\mathrm{n}(\%)$ & $3(20)$ & 0 & 0.16 \\
- Sjögren Syndrome & 2 & & \\
Abnormalities in thorax Rx. $\mathrm{n}(\%)$ & $3(20)$ & 0 & 0.16 \\
Dyspnea, $\mathrm{n}(\%)$ & $1(6.7)$ & 0 & 0.60 \\
DMARD, $\mathrm{n}(\%)$ & 8 & 4 & 0.60 \\
Methotrexate, $\mathrm{n}(\%)$ & $5(55)$ & $2(50)$ & \\
Hydroxichloroquine, $\mathrm{n}(\%)$ & $2(33)$ & $2(50)$ & \\
Sulfasalazine, $\mathrm{n}(\%)$ & $1(12)$ & 0 & \\
\hline
\end{tabular}

Conclusions: We find a high frequent of lung involvement in early RA, in most of cases subclinical. Performing Respiratory function tests may help in early detection of lung involvement. These results should be ratified in larger series.

Disclosure of Interest: None declared

DOI: 10.1136/annrheumdis-2017-eular.3267

\section{AB0198 DIFFERENTIAL CHARACTERISTICS OF PATIENTS DISCONTINUATING SEVERAL BIOLOGICAL THERAPIES IN A COHORT OF RHEUMATOID ARTHRITIS PATIENTS}

C. Tornero ${ }^{1}$, C. Plasencia ${ }^{1}$, D. Pascual-Salcedo ${ }^{2}$, B. Hernández ${ }^{1}$ M. González ${ }^{1}$, M.G. Bonilla ${ }^{1}$, L. Nuño ${ }^{1}$, A. Villalba ${ }^{1}$, D. Peiteado ${ }^{1}$, P. Bogas ${ }^{1}$ E. Moral ${ }^{1}$, A. Balsa ${ }^{1} .{ }^{1}$ Rheumatology; ${ }^{2}$ Immunology, la Paz University Hospital, Madrid, Spain

Background: The treatment of Rheumatoid Arthritis (RA) has been transformed in the last decade with the introduction of biologic therapy. Nevertheless, a substantial proportion of patients (pts) are found to be primary or secondary nonresponders and will receive several biologics during the course of the disease. Evidence is lacking on the characterization of patients failing several agents and those who have adequate clinical response to their first biological treatment.

Objectives: To compare demographic, clinical and analytical characteristics in a cohort of RA pts who have failed treatment with at least two biological agents ("switchers") and another cohort of RA patients showing a sustained clinical good response to their first therapy ("maintainers"). As a secondary objective, reasons for therapy discontinuation were also evaluated.

Methods: A total of 186 patients under biological therapy of the RA-PAZ cohort were included in this observational study. In this cohort, 63 pts were switchers and 123, maintainers. Baseline demographic data and clinical disease activity (DAS 28 -ESR), clinical improvement (delta-DAS 28) and serological data (CRP and ESR) were evaluated at baseline and sixth months after starting the first biological treatment.Serum anti-drug antibodies (ADA) were measured by bridging ELISA at the last visit available during the follow-up period under the first treatment. Reasons for discontinuation of the first therapy and the number of biologic treatments received during the course of the disease were also evaluated.

Results: Demographic and clinical characteristics of both groups are shown in Table 1.Mean Age $(49,96 \pm 10,82$ vs $53,77 \pm 12,91, p=0,046)$ and disease duration $(6,79 \pm 6,19$ vs $9,97 \pm 8,56, p=0,001)$ prior to biologic therapy initiation were lower in the switchers.Furthermore, a higher proportion of switchers had extraarticular manifestations in comparison to the maintainers (18/63 $(28,6 \%)$ vs $16 / 121(13,2 \%), p=0,016)$. Clinical activity at baseline (DAS28: $5,74 \pm 1,26$ vs $5,01 \pm 1,14, p=0,01)$ and after 6 months of starting the first biological therapy (DAS28: $4,45 \pm 1,6$ vs $3,22 \pm 1,1, p=0,001$ ) were statistically significant higher in the switchers. At the last visit under the first biologic, there were also more ADA-positive pts in the switchers $(6 / 25(24 \%)$ vs $1 / 73(1,4 \%)$, $\mathrm{p}=0,01)$. Moreover, duration under biologic treatment was higher in this group. In terms of the reason for discontinuation of the first biologic, $22,2 \%$ of pts showed primary lack of efficacy; $38,1 \%$, secondary loss of efficacy; $33,3 \%$, adverse effects; $4,8 \%$ interrupted because of other reasons and $1,6 \%$ because of

\begin{tabular}{|c|c|c|c|}
\hline Pts characteristics & $\begin{array}{l}\text { Switchers } \mathrm{n}= \\
63\end{array}$ & $=\begin{array}{l}\text { Maintainers } \\
\mathrm{n}=123\end{array}$ & $P$ value \\
\hline \multicolumn{4}{|c|}{$\begin{array}{l}\text { Baseline characteristics at the initiation of the 1st biological therapy } \\
\text { (1BT) }\end{array}$} \\
\hline Female, $\mathrm{nN}(\%)$ & $\begin{array}{l}49 / 63 \\
(77,8 \%)\end{array}$ & $\begin{array}{l}102 / 122 \\
(83,6 \%)\end{array}$ & Ns \\
\hline $\mathrm{BMI}(\mathrm{kg} / \mathrm{m} 2.) \pm \mathrm{DS}$ & $27,31 \pm 5,37$ & $26,23 \pm 4,96$ & NS \\
\hline $\begin{array}{l}\text { Smoking habit } \\
\text { - Non-smoker } \\
\text { - Smoker } \\
\text { - Ex smoker }\end{array}$ & $\begin{array}{l}38 / 61(62,3 \% \\
11 / 61 / 18 \%) \\
12 / 61(19,7 \%\end{array}$ & $\begin{array}{l}69 / 115(60 \%) \\
19 / 115(16,5 \% \\
27 / 115(23,5 \%)\end{array}$ & NS \\
\hline $\begin{array}{l}\text { Age at the starting of the } 1 \mathrm{BT}= \\
\text { DS }\end{array}$ & $49,96 \pm 10,82$ & $253,77 \pm 12,91$ & $\begin{array}{l}P= \\
0,046\end{array}$ \\
\hline $\begin{array}{l}\text { Time from diagnosis to } 1 \mathrm{BT} \pm \\
\text { DS (y) }\end{array}$ & $6,79 \pm 6,19$ & $9,97 \pm 8,56$ & $\begin{array}{l}P= \\
0,001\end{array}$ \\
\hline Co-therapy (DMARDs) \pm DS & $27,31 \pm 5,37$ & $26,22 \pm 4,96$ & NS \\
\hline $\begin{array}{l}\text { Auto-antibodies (U//ml) } \\
-\mathrm{FR}+, \mathrm{n} N(\%) \\
-\mathrm{ACPA}+, \mathrm{nN}(\%)\end{array}$ & \begin{tabular}{|l|}
$50 / 63$ \\
$(79,4 \%)$ \\
97118 \\
$(82,2 \%)$ \\
\end{tabular} & $\begin{array}{l}93 / 121(76,9 \%) \\
53 / 62(85,5 \%)\end{array}$ & NS \\
\hline Erosions, $\mathrm{n} / \mathrm{N}(\%)$ & $\begin{array}{l}36 / 52 \\
(69,2 \%)\end{array}$ & $67 / 101(66,3 \%)$ & Ns \\
\hline $\begin{array}{l}\text { Extraarticular manifcstations, } \\
\text { n N }(\%)\end{array}$ & $18 / 63(28,6 \%$ & $16 / 121(13,2 \%)$ & $\begin{array}{l}P= \\
0,011\end{array}$ \\
\hline Monotherapy, $\mathrm{n} / \mathrm{N}(\%)$ & $3 / 63(4,8 \%)$ & $6 / 122(4,9 \%)$ & NS \\
\hline $\begin{array}{l}\text { Baseline activity } \pm \mathrm{DS} \\
-\mathrm{DAS}-28 \neq \mathrm{DS} \\
-\mathrm{PCR} \pm \mathrm{DS} \\
-\mathrm{VSG} \pm \mathrm{DS}\end{array}$ & $\begin{array}{l}5,74 \pm 1,26 \\
13,82 \pm 20,8 \\
33,63 \pm 22,03\end{array}$ & $\begin{array}{l}5,01 \pm 1,14 \\
10,26 \pm 13,6 \\
29.4 \pm 18,36\end{array}$ & $\begin{array}{l}\mathrm{P}=0,001 \\
\mathrm{NS} \\
\mathrm{NS} \\
\mathrm{N}\end{array}$ \\
\hline \multicolumn{4}{|c|}{6 months after the initiation of the 1st biological therapy } \\
\hline $\begin{array}{l}\text { Six months activity } \pm \text { DS } \\
\text { - DAS-28 }=\text { DS } \\
- \text { Delta-DAS } 28 \pm \text { DS }\end{array}$ & $\mid \begin{array}{l}4,44=1,61 \\
1,40 \pm 1,6\end{array}$ & $\begin{array}{l}3,22=1,10 \\
1,77 \pm 1,2\end{array}$ & $\begin{array}{l}\mathrm{P}= \\
0,001 \\
\mathrm{NS}\end{array}$ \\
\hline \multicolumn{4}{|l|}{$\begin{array}{l}\text { Last visit available after the } \\
\text { initiation of the } 1 \mathrm{BT}\end{array}$} \\
\hline $\mathrm{ADA}^{+}, \mathrm{n} / \mathrm{N}(\%)$ & $6 / 25(24 \%)$ & $1 / 73(1,4 \%)$ & $\mathrm{P}=0,01$ \\
\hline \multicolumn{4}{|c|}{$\begin{array}{l}\text { At the last visit available after the initiation of the 1st biological } \\
\text { therapy }\end{array}$} \\
\hline Age, mean $\pm \mathrm{DS}$ & $61,23 \pm 11,8$ & $61,05 \pm 12,8$ & NS \\
\hline $\begin{array}{l}\text { Time of follow-up until } \\
\text { the last visit available } \pm \text { DS, } \\
\text { (years) }\end{array}$ & $16,48 \pm 7,5$ & $16,71 \pm 9,9$ & NS \\
\hline $\begin{array}{l}\text { Mean time under biologic } \pm \mathrm{DS} \text {, } \\
(\mathrm{y})\end{array}$ & $9,48 \pm 4,3$ & $6,72 \pm 4,6$ & \\
\hline
\end{tabular}

